\title{
PRELIMINARY ASSESSMENT OF \\ TREE MORTALITY NEAR F- AND \\ H-AREA SEEPAGE BASINS
}

\author{
CRAIG LOEHLE \\ JOHN GLADDEN
}

Environmental Sciences Division

Savannah River Laboratory

E. I. du Pont de Nemours and Company, Inc.

Aiken, South Carolina 29808-0001

\section{NOT FOR PUBLIC DISSEMINATION}

Mraymantain Unclassified Controlled urar

Information miect to section of the

Atomic Energy Aca as amended (42 USC 210, Approval by mmepartment of - gy prior to release is required. 


\section{SUMMARY}

A preliminary assessment was conducted to evaluate factors that may have been responsible for the vegetation damage that has occurred in groundwater seeps downslope from the F- and $\mathrm{H}$-area seepage basins. The factors that were considered included altered hydrology, toxicity from hazardous chemical constituents associated with seepage basin operation, and toxicity from non-hazardous constituents associated with basin operation. It was concluded that the observed damage was not likely to have resulted from altered hydrologic conditions or hazardous constituents associated with basin operation. Insufficient information is currently available to determine definitively which of the nonhazardous constituents, alone or in concert, were responsible for the observed vegetation damage. The most likely explanation, however, is that elevated $\mathrm{Na}, \mathrm{pH}$, and conductivity in outcropping seep water are responsible for tree mortality. All three of these factors will return to ambient levels over a period of several years when basin operation ceases. Faster remediation can be achieved using lime at the seep line.

\section{BACKGROUND}

The F- and H-Area seepage basins began operation in 1955, receiving non-radioactive and low level radioactive liquid waste from the operation of the $\mathrm{F}$ and $\mathrm{H}$ separations areas on the SRP. The operation, estimated loadings and current status of these basins are summarized in Killian et al. (1987 a, b). Seepage from these basins enters the groundwater and moves downslope where some of the contaminated groundwater outcrops into wetland areas near, or on, the floodplain of Four Mile Creek. Evidence indicates that some constituents of the liquid waste reached the seepage outcrop areas by the mid-1960's (Fenimore and Horton, 1972). Jensen and Mackey (1988 a, b) determined that damage had occurred to vegetation in areas downslope from both the F- and H-Area seepage basins at points where the groundwater plumes from the seepage basins is expected to outcrop. Subsequent ground-level investigations confirmed that trees in these wetland seep areas were either dead or severely stressed and chemical analyses of seep area water samples 
confirmed that the surface waters in several of these wetlands was strongly influenced by constituents from the F- and H-Area seepage basins (Looney et al., 1988); elevated levels of nitrate and sodium were considered to be distinctive signatures for waters originating in the seepage basins. Subsequently, Mackey (1988) determined that the tree canopy loss in seep areas associated with both the F- and H-Area basins occurred over a very short time period in 1979-80, indicating a 25 year lag from initiation of basin operations to tree mortality effects. Preliminary dendrochronological analyses of living trees adjacent to the seep areas have shown that trees exhibited a growth suppression sometime between 1978 and 1980 (David LeBlanc, personal communication).

This preliminary evaluation was undertaken to determine the probable causes of the observed tree stress and mortality in the F- and H-Area seepage basin outcrops along the north edge of Four Mile Creek. Three general classes of stresses were considered:

- hydrologic changes resulting from hydraulic loading to the seepage basins,

- chemical stress attributable to high concentrations of hazardous constituents (see 40 CFR Part 261, Appendix VIII) associated with seepage basin operations,

- chemical stress resulting from non-hazardous constituents associated with seepage basin operations.

Each of these potential causes of the observed vegetation damage were evaluated using existing data and literature.

\section{RESULTS}

\section{Hydrologic Changes}

The seepage areas where trees are dying were inspected in November 1987. It was noted that virtually all of the dead and dying trees were swamp tupelo (Nyssa sylvatica var. biflora [Walt.] Sarg.), growing in almost pure stands on highly organic, saturated, mucky soils. Dead trees range from 6 to 10 in. dbh. Swamp tupelo is highly tolerant of waterlogged soil, being less tolerant than bald cypress but more tolerant than other swamp associates (Hook, 1984). It tolerates prolonged shallow flooding. In a study in Florida, 
greater than $50 \mathrm{~cm}$ flooding over several years was necessary to produce detectable mortality (Table 1) in the size classes present in the F-and H-Area seeps. Teskey and Hinckley (1977) concluded that swamp tupelo was tolerant of partial submersion and moderate siltation.

There are several hydrologic mechanisms that could result in tree death. Each will be considered in turn as hypotheses.

Hypothesis 1: Permanent low-level flooding of previously unflooded soil which resulted in tree death.

Evidence:

A. Soils in which tupelo grows in the seeps is organic muck, indicating that the area has a history of saturation longer than the number of years since tree mortality has been evident.

B. Transition from muck to upland soil is abrupt and follows topographic boundaries. Muck-upland soil transition matches wet-dry transition and vegetation transition. These facts indicate against a recent rise in water table.

C. Permanent flooding of only a few centimeters is not likely to kill an entire stand of swamp tupelo.

D. A 25 year lag from basin opening to tree mortality is inconsistent with a hydrologic cause of tree death, whereas chemistry of the basins may have changed during this period.

Hypothesis 2: Siltation of floodplain resulted in root burial and tree death.

Evidence:

A. Siltation is only evident in the part of the H-Area seep closest to the basin and thus could not have killed trees in most of the area. The silt in this location probably results from erosion from the forest clearcut a few tens of meters away and is thus less than two years old. Some of it may also have come from a drainage ditch originating near the burial grounds and recent construction activities near the basins.

Hypothesis 3: Periodic deep flooding killed the trees.

Evidence:

A. Periodic flooding deep enough to kill tupelo should have killed trees on the adjacent upland soil, although analysis of increment cores does indicate that these upland trees are stressed (D. LeBlanc, pers. comm.).

B. Wetland herbaceous and shrub vegetation should have established upslope from the muck soil type if chronic flooding was occurring, but have not.

C. There is no evidence of high water mud marks on the trees. 
D. There is sufficient drainage of the area to prevent deep flooding without major flooding downstream. Even at low water levels evident in December, water was flowing out of the area.

From the evidence available, it is necessary to reject hypotheses two and three. While the evidence is against a solely hydrologic cause for tree mortality in these seeps, such a cause can not be ruled out entirely because water tupelo varies geographically in its flood tolerance (Harmes et al., 1980; Hook 1984).

\section{Hazardous Constituents}

Looney et al. (1988) provided chemical analyses of seep area water. Among the Appendix VIII constituents considered to be of interest for the F- and H-Area seepage basins, lead, nickel, chromium, mercury and barium were all below the National Primary Drinking Water Standard (NPDWS). Cadmium levels were below detection limits in the H-Area seeps (as were most of the Appendix VIII constituents), but above the NPDWS of $0.01 \mathrm{mg} / \mathrm{L}$ at the F-Area seeps. Nevertheless, Adriano (1986) indicated that crop plants are generally not affected at these levels, and that tree species appear less sensitive to cadmium than crops. Consequently, neither cadmium, nor any of the other Appendix VIII constituents are believed to be causing the vegetation damage in the $\mathrm{F}$ - and $\mathrm{H}$-Area wetland seeps. This conclusion is further supported by the evidence that the loss of tree canopy occurred simultaneously at both the F-and H-Area wetland seeps, although Appendix VIII constituents at the $\mathrm{H}$-Area seeps are generally below detection limits.

\section{Non-Hazardous Constiments}

The results of Looney et al. (1988) indicate that concentrations of several nonhazardous (i.e., not Appendix VIII) constituents are elevated at the groundwater seeps downslope from the F- and H-Area seepage basins. Conductivity, total dissolved solids, alkalinity, nitrate, phosphate, carbon, and sodium were all substantially elevated in both seep areas relative to levels in nearby Four Mile Creek. Other selected constituents were 
moderately elevated in the H-Area seep, while concentrations of hydrogen ion $(\mathrm{pH})$, silica, calcium, magnesium, aluminum and zinc were substantially elevated (relative to Four Mile Creek water) in the F-Area seep.

The $\mathrm{pH}$ of the F-Area seep water is slightly low (about 3.8) and could have been lower in the recent past. This could have had a negative effect on trees especially over a prolonged period. The $\mathrm{pH}$ of the H-Area seep water is typical (about 7) for the area, possibly due to greater buffering capacity of soils there (B. Looney, pers. comm.). F-Area seep conductivity is in the range where it may be causing substantial stress (Table 2). HArea seep conductivity may be causing some stress. More detailed information on conductivity effects can be found in Holmes et al., (1966), Langille (1974), and Shortle and Rich (1970). Aluminum in the F-Area seep is very toxic (33 times the toxic level). Aluminum in the H-Area seep should not be causing mortality but might be stressful. When $\mathrm{Na}$ gets too high it interferes with $\mathrm{K}$ uptake and the $\mathrm{Na} / \mathrm{K}$ ratio in both $\mathrm{F}$ - and $\mathrm{H}$ Areas is significantly higher than the control areas, indicating possible toxicity. Sodium per se is at or above toxic levels in both areas (Table 2).

In summary, altered water chemistry is the most likely candidate for causing tree mortality. Several aspects of water chemistry probably contribute to stress. There is less live vegetation in F-Area, where water chemistry deviates more markedly from control values, supporting this conclusion. Exact explanations of chemistry effects can not be made because current groundwater chemistry is not necessarily the same as that which caused mortality several years ago. The worst episodes are likely to be more related to tree mortality than the averages. The components hypothesized to be toxic would probably quickly return to normal if input to the basins stopped. Natural flushing of swamp soils would return $\mathrm{Na}, \mathrm{pH}$, and conductivity to normal. Reduced $\mathrm{H}^{+}$concentration (increased $\mathrm{pH}$ ) would decrease aluminum solubility and would force aluminum to gradually return to mineral form. Mobility of other metals would also be drastically reduced at a higher $\mathrm{pH}$. 
This process could be accelerated by putting limestone rock in the water at the seep line, though this may not be needed. 


\section{Literature Cited}

Adriano, D. C. 1986. Trace elements in the Terrestrial Environment. Springer-Verlag, New York.

Bresler, E., B. L. McNeal and D. L. Carter. 1982. Saline and Sodic Soils: PrinciplesDynamics-Modeling. Springer - Verlag, N. Y.

Fenimore, J. W. and Horton, J. H. 1972. Operating history and environmental effects of seepage basins in chemical separations areas of the Savannah River Plant, DPST-72548. Savannah River Laboratory, E. I. du Pont de Nemours and Company, Inc.

Harms, W. R., H. T. Schreuder, D. D. Hook, C. L. Brown, and F. W. Shropshire. 1980. The effects of flooding on the swamp forest in Lake Ocklawaha, Florida. Ecology 6: 1412-1421.

Holmes, F. W., and Baker, H. H., 1966. Salt Injury to Trees II, Phytopathology, 56, pp. 633-636.

Hook, D. D. 1984. Waterlogging tolerance of lowland tree species of the South. S. J. Appl. For. 8: 136-149.

Jensen, J. R. and H. E. Mackey, Jr. 1988a. Analysis of vegetation stress associated with F-Area and H-Area seepage basins using digital remote sensing data for April 1985. DPST-88-255, Savannah River Laboratory, E. I. Du Pont de Nemours and Company, Inc. 
Jensen, J. R. and H. E. Mackey, Jr. 1988b. Identification of stress areas associated with H- and F-Area seepage basins using high-resolution aircraft MSS data for April 1987. DPST-88-256, Savannah River Laboratory, E. I. Du Pont de Nemours and Company, Inc.

Killian, T. H., N. L. Kolb, P. Corbo, and I. W. Marine. 1987a. Environmental information document: F-Area seepage basins. DPST-85-704, Savannah River Laboratory, E. I. Du Pont de Nemours and Company, Inc.

Killian, T. H., N. L. Kolb, P. Corbo, and I. W. Marine. 1987b. Environmental information document: H-Area seepage basins. DPST-85-706, Savannah River Laboratory, E. I. Du Pont de Nemours and Company, Inc.

Langille, A. R., 1974. Salt Toxicity of Conifers. Maine Department of Transportation, Technical Paper No. 74-5.

Looney, B. B., J. E. Cantrell, and J. R. Cook. 1988. Sampling and analysis of surface water in the vicinity of the F- and H-Area seepage basins. DPST-88-229.

Lower, M. W. 1987. Comprehensive Cooling Water Study Final Report, Volume II: Water Quality. DP-1739-2. Savannah River Laboratory. E. I. Du Pont de Nemours and Co., Inc. Aiken, SC.

Mackey, H. E., Jr. 1988. Initial evaluation of photographic data of F- and H-Area seepage basin outcrops. DPST-88-314. 
Moore, D. P. 1974. Physiological effects of $\mathrm{pH}$ on roots. In: E. W. Carson (ed.) The $=$ Plant Root and It's Environment. Univ. Press of Virginia, Charlotteville. p. 135-151.

Shortle, W. C., and A. E. Rich. 1970. Relative Sodium Chloride Tolerance of Common Roadside Trees in Southeastem New Hampshire. Plant Disease Reporter, 54.

Teskey, R. O., and T. M. Hinckley. 1977. Impact of Water Level Changes on Woody Riparian and Wetland Communities. Vol. II: Southern Forest Region. FWS/OBS77/59. U. S. Fish and Wildlife Service, U. S. Department of Interior, Washington, D. C. 
Table 1. Cumulative percent mortality of gum in Lake Ocklawaha ${ }^{1}$

\begin{tabular}{|c|c|c|c|c|c|c|}
\hline \multirow[t]{2}{*}{ Site } & \multirow[t]{2}{*}{$\begin{array}{l}\text { Water Depth } \\
\text { Apr. } 1972 \\
(\mathrm{~cm})\end{array}$} & \multirow[t]{2}{*}{$\begin{array}{l}\text { No. trees } \\
\text { Fall } 1968\end{array}$} & \multicolumn{4}{|c|}{ Cumulative $\%$ mortality } \\
\hline & & & $\begin{array}{l}\text { Apr } \\
1972 \\
\end{array}$ & $\begin{array}{l}\text { Nov } \\
1972 \\
\end{array}$ & $\begin{array}{l}\text { Feb } \\
1975 \\
\end{array}$ & $\begin{array}{l}\text { Aug } \\
1975 \\
\end{array}$ \\
\hline Control 1 & 29.2 & 62 & 0 & 0 & & 0 \\
\hline \multicolumn{7}{|l|}{0} \\
\hline Control 2 & 24.1 & 99 & 2 & 2 & 2 & 2 \\
\hline 1 & 20.3 & 72 & 0 & 0 & 0 & 3 \\
\hline 2 & 52.1 & 25 & 0 & 0 & 0 & 0 \\
\hline 3 & 65.8 & 54 & 5 & 5 & 5 & 5 \\
\hline 4 & 82.3 & 72 & 3 & 14 & 14 & 14 \\
\hline 5 & 107.2 & 79 & 31 & 59 & 59 & 59 \\
\hline 6 & 120.6 & 131 & 91 & 91 & 100 & 100 \\
\hline
\end{tabular}

1Lake impounded in 1968. (From Harms et. al., 1980). 
Table 2. Comparison of water chemistry at F- and H-Area seeps to control sites and toxic levels.

\begin{tabular}{|c|c|c|c|c|}
\hline & $\begin{array}{l}\text { F-Area } \\
(001,007 \\
\text { and 013) }\end{array}$ & $\begin{array}{l}\text { H-Area } \\
(002,008, \\
\text { and 014) }\end{array}$ & $\begin{array}{l}\text { Non-impacted } \\
\text { control sites } \\
(003,005,009 \\
011,015, \text { and } 017)\end{array}$ & $\begin{array}{l}\text { Toxic } \\
\text { levels }\end{array}$ \\
\hline \multicolumn{5}{|c|}{ Conductivity } \\
\hline$(\mu S / \mathrm{cm})$ & 1683 & 342.0 & 56.0 & $2000^{1}$ \\
\hline \multicolumn{5}{|l|}{ Aluminum } \\
\hline$(\mathrm{mg} / \mathrm{l})$ & 65.7 & 0.16 & $<0.05$ & $2.0^{2}$ \\
\hline $\mathrm{Na}(\mathrm{mg} / \mathrm{l})$ & 140.7 & 68.6 & $7.5^{3}$ & $6-69^{1}$ \\
\hline
\end{tabular}

Means were taken of replicate samples and sites. Data collated from Looney et al. (1988) except for toxicity data. Numbers 001-017 correspond to site numbers in Looney et al. (1988). Toxic levels are approximation and do not reflect specific studies at SRP with tupelo.

${ }^{1}$ From Bresler et al. (1982).

2From Moore (1974).

${ }^{3}$ Calculated from average of standing water swamp sites at SRP river swamp (Lower, 1987). 